\title{
The Effect of Capital Structure and Inventory Turnover on Net Income through Net Sales in Food and Beverage Companies on the Indonesia Stock Exchange 2015 - 2019 Period
}

\author{
Andar Klemen Penuam ${ }^{1}$, Mohammad Burhan², Edi Subiyantoro ${ }^{3}$ \\ ${ }^{1}$ Student in Magister Management Program, University of Merdeka Malang, Indonesia \\ ${ }^{2,3}$ Lecturer in Faculty of Economics and Business, University of Merdeka Malang, Indonesia
}

\begin{abstract}
This study was conducted to examine the effect of capital structure and inventory turnover on net income through net sales. This research was conducted in the food and beverage industry listed on the Indonesia Stock Exchange for 2015 - 2019. This research is a quantitative study with the type of causality research. The sample of this study includes 18 companies selected through the purposive sampling technique. Secondary data collection uses the company's financial statement documentation and other supporting literature. The analytical method used is descriptive analysis, multiple linear regression analysis, and path analysis. The results of this study indicate that the capital structure has no effect on net income through net sale, while inventory turnover has an effect on net income through net sales.
\end{abstract}

Keywords: Capital Structure, Inventory Turnover, Net Sales, Net Profit.

\section{INTRODUCTION}

The current economic conditions have created a tight competition between companies in the industry. This competition makes every company improve its performance so that its goals can still be achieved. Basically, the purpose of a company is to generate profits for its owners. This is in accordance with the economic principle, namely with a small sacrifice, you can get maximum results. [1-2].

Food and beverage sub-sector companies have a significant contribution to economic growth. The prospect of this industry is very good because basically food and beverage products are one of the basic needs of the community in daily life. [3].

For potential investors, the food and beverage industry is quite attractive because it is an industry that continues to survive in conditions of economic competition in Indonesia. Its development is expected to provide good prospects in meeting the needs of the community. [4].

The company really needs potential investors and must keep the old investors as one of the supporters of the company's survival. Usually investors or potential investors have to collect information or data as consideration in making decisions to invest. One of them is the profit information generated by the company every year.

The net profit generated by a company can describe the growth and performance of the company. If the company's performance is good, this will have a good impact on the company. Because potential investors will be easily attracted to invest, while old investors will continue to stay in the company. [5].

Profit is very important for internal and external parties. For externals, information about earnings is a consideration for investment decisions. As for internal, profit is one of the sources of company funds to keep operating. The size of the profit is influenced by several factors. Some of them are capital structure, inventory turnover and sales. [6].

Large capital has the potential to encourage company growth, including in generating profits. Many companies decide to use debt as a source of funding. In this study, the company's capital structure is seen from the debt to equity ratio, which is the company's funding sourced from debt. This debt ratio can have a good or bad influence on the company's profit growth. Therefore, an optimal capital structure and good management are needed so that it can encourage the company's profit growth. [7].

Several previous studies were conducted to measure the effect of capital structure on sales and profits. Research by Bunga and Sofie concludes that the capital structure as measured by the debt to equity ratio has a positive effect on profitability as measured by Return On Equity. The company's capital structure which tends to be dominated by debt will increase the interest expense borne by the company, resulting in a decrease in company income, but the tax that must be paid by the company will be 
small. Vice versa, the company's capital structure which tends to be dominated by its own capital will reduce the interest expense borne by the company, resulting in an increase in company income or large profits, but the taxes that must be paid by the company are also large. [8].

The same results were also obtained by Erlina and Junianto, Rizka and Nanu. They conclude that an optimal capital structure and good management will be followed by an increase in sales and operating profit. [9-10].

In addition to the capital structure, inventory and sales turnover also affects the company in generating profits. If the inventory turnover is high, sales are also high so that the profit generated is also large. However, low inventory turnover can be a burden for the company because the inventory does not sell well, considering that the inventory has an expiration date. This shows that when there is an increase in inventory turnover, profit has the potential to increase. On the other hand, if inventory turnover decreases, profits will also decrease. Therefore, every company will try to maximize sales, so that inventory turnover is higher so as not to experience losses. [11-12].

\section{LITERATURE REVIEW}

\section{a. Capital Structure}

The capital structure is equity and debt funding in companies which are often measured in terms of the relative size of various funding sources, the company's financial stability and bankruptcy risk depending on the funding source and the type and amount of various assets owned. [13].

The problem of capital structure is an important problem for every company, because the good or bad of the capital structure, will affect the company's financial position. One of the important contents that is often faced by managers of a company is determining the right balance between debt and equity.

\section{b. Inventory Turnover}

According to Kasmir, inventory turnover is a ratio used to measure the number of times the funds invested in inventory rotate in one period. Inventory turnover shows how long the inventory of goods in the company can be sold for one year. This is calculated by comparing the cost of goods sold with the average inventory. [14].

Poor inventory management can lead to shortages and excess inventory of goods. Inventory shortages can result in delivery failures, lost sales, dissatisfied customers and production stagnation. Excess inventory can increase storage costs and the risk of damage to goods. [15].

\section{c. Net sales}

According to Mulyadi, sales are activities carried out by sellers and in selling goods and services with the dream of getting profits from the existence of these transactions and sales can be interpreted as transferring or transferring ownership rights to goods or services. from the seller to the buyer. [16].

In theory, net sales are all sales proceeds, both cash and credit, minus commissions, discounts and sales returns and other deducting factors. So, it can be concluded that in general the factors that affect net sales are sales returns and allowances and sales discounts.

\section{d. Net profit}

Earnings or net income indicates the company's profitability. Earnings reflect returns to holders of equity for the period, while items in the report detail how profits were earned. Profit is the result of a comparison between income and expenses. [17-18].

Net income is the positive difference on sales less costs and taxes. The understanding of profit adopted by accounting organizations today is accounting profit which is a positive difference between revenues and costs. 


\section{e. Conceptual Framework}

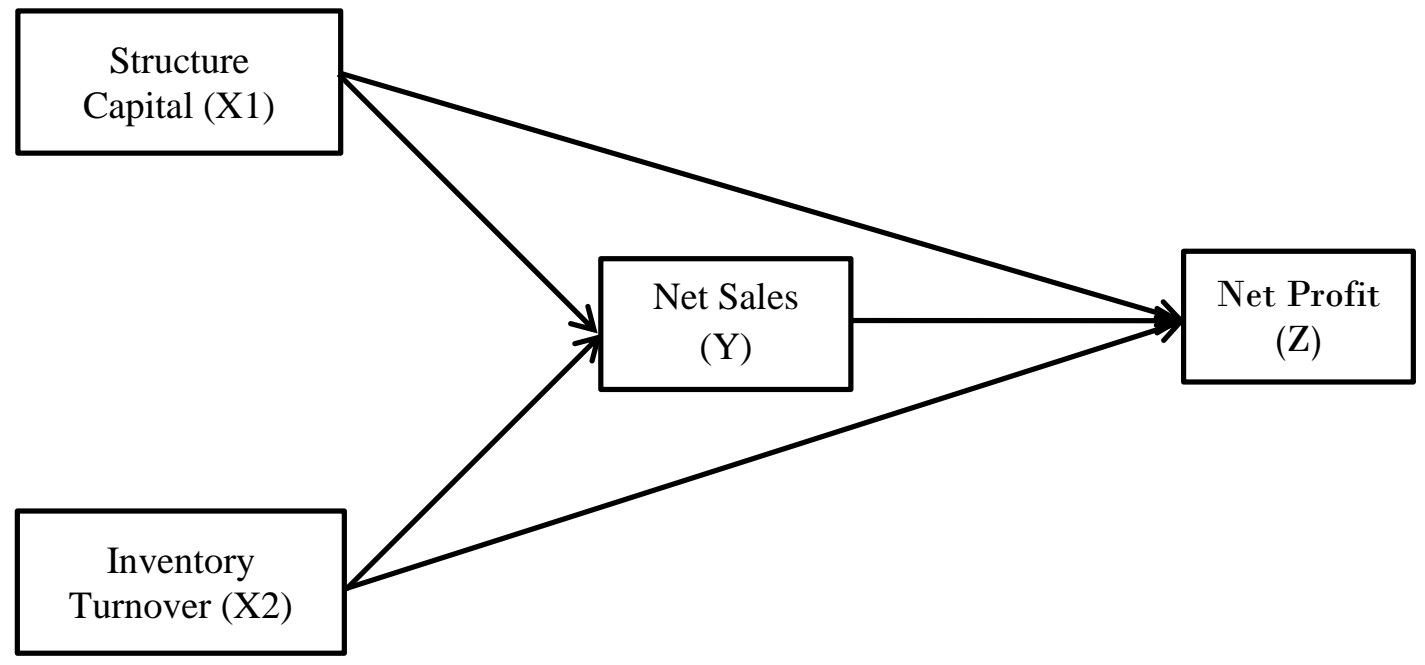

Figure 1: Conceptual Framework

$\mathrm{X} 1, \mathrm{X} 2$ = independent variable

$\mathrm{Y}=$ mediating variable

$\mathrm{Z}=$ dependent variable

\section{f. Hypothesis}

The hypotheses in this study are:

1) Capital structure and inventory turnover have a positive effect on net sales.

2) Capital structure and inventory turnover have a positive effect on net income.

3) Capital structure and inventory turnover have a positive effect on net income through net sales.

\section{RESEARCH METHOD}

\section{a. Population and Sampling Techniques}

The population in this study are manufacturing companies in the goods and consumption sector, food and beverage subsectors listed on the Indonesia Stock Exchange (IDX) in the 2015-2019 period. In this study, the sampling technique used is purposive sampling. Purposive sampling is a probability sampling method carried out with certain criteria. With this technique, the research sample is 18 food and beverage companies listed on the Indonesia Stock Exchange for the 2015-2019 period.

\section{b. $\quad$ Research Variable}

In this study there are 3 variables used, namely:

1) Independent Variable

There are 2 independent variables used in this study, namely:

(a) Capital Structure

Capital structure can be measured by the formula:

(b) Inventory Turnover

$$
\text { Debt to Equity Ratio }=\frac{\text { Totol Debt }}{\text { Equity }}
$$

Inventory turnover can be measured by the formula:

$$
I T R=\frac{\text { Cost of goods sold }}{\text { Average Inventory }}
$$


2) Dependent Variable

The dependent variable used is Net Profit. Net profit can be measured by the formula:

3) Mediation Variable

$$
\text { Net Profit }=\frac{\text { Net Profit }}{\text { Net Sales }} \times 100 \%
$$

The mediating variable used in this research is Net Sales. Net Sales can be measured by the formula:

$$
\text { Net Sales }=\text { Total Sales }- \text { Sales Discounts and Returns }
$$

\section{RESEARCH RESULT}

This path analysis technique will be used in testing the amount of contribution (contribution) indicated by the path coefficient on each path diagram of the causal relationship between the variables of Capital Structure (X1) and Inventory Turnover (X2)2, to Net Profit (Z) through Net Sales ( Y). Correlation and regression analysis are the basis for calculating path analysis.

Table 1. Effect of Capital Structure and Inventory Turnover on Net Sales

\begin{tabular}{|l|c|c|c|}
\hline \multicolumn{1}{|c|}{ Independent Variable } & Beta & $\boldsymbol{t}$ & Sig. \\
\hline Capital Structure & -0.002 & -0.017 & 0.986 \\
\hline Inventory Turnover & -0.181 & -1.676 & 0.097 \\
\hline \multicolumn{2}{|c|}{ Dependent Variable } & \multicolumn{3}{|c|}{ Net sales } \\
\hline
\end{tabular}

In accordance with the results of SPSS above, it can be seen that the significance value of the two independent variables, namely the capital structure (X1) is 0.986, while the inventory turnover (X2) is 0.097. The significance value of the two variables is greater than 0.05 , which means $\mathrm{Ha}$ is rejected so that the conclusions that can be drawn are variables X1 and X2 have no effect on variable $\mathrm{Y}$.

Table 2. Effect of Capital Structure and Inventory Turnover on Net Profit

\begin{tabular}{|l|c|c|c|}
\hline \multicolumn{1}{|c|}{ Independent Variable } & Beta & $\boldsymbol{t}$ & Sig. \\
\hline Capital Structure & -0.102 & -1.238 & 0.219 \\
\hline Inventory Turnover & -0.512 & -6.085 & 0.000 \\
\hline \multicolumn{1}{|c|}{ Dependent Variable } & \multicolumn{3}{|c|}{ Net Prrofit } \\
\hline
\end{tabular}

Source: Processed secondary data (2021)

Based on the table above, it can be seen that the capital structure variable (X1) has a significance value of $0.219>0.05$ so it can be concluded that there is no effect of the capital structure variable (X1) on the dependent variable, namely net income (Z). The inventory turnover variable (X2) has a significance value of $0.000<0.05$ so it can be concluded that there is an effect of the inventory turnover variable (X2) on the dependent variable, namely net income (Y).

Table 3. Effect of Net Sales on Net Profit

\begin{tabular}{|l|c|c|c|}
\hline Independent Variable & Beta & \multicolumn{1}{c|}{ Sig. } \\
\hline Net Sales & 0.296 & 3.608 & 0.001 \\
\hline Dependent Variable & \multicolumn{3}{|c|}{ Net Profit } \\
\hline
\end{tabular}

The net sales mediation variable (Y) has a significance value of $0.001<0.05$ so it can be concluded that the net sales variable (Y) has an effect on net income. Based on the above calculations, the path analysis is presented in the following figure: 


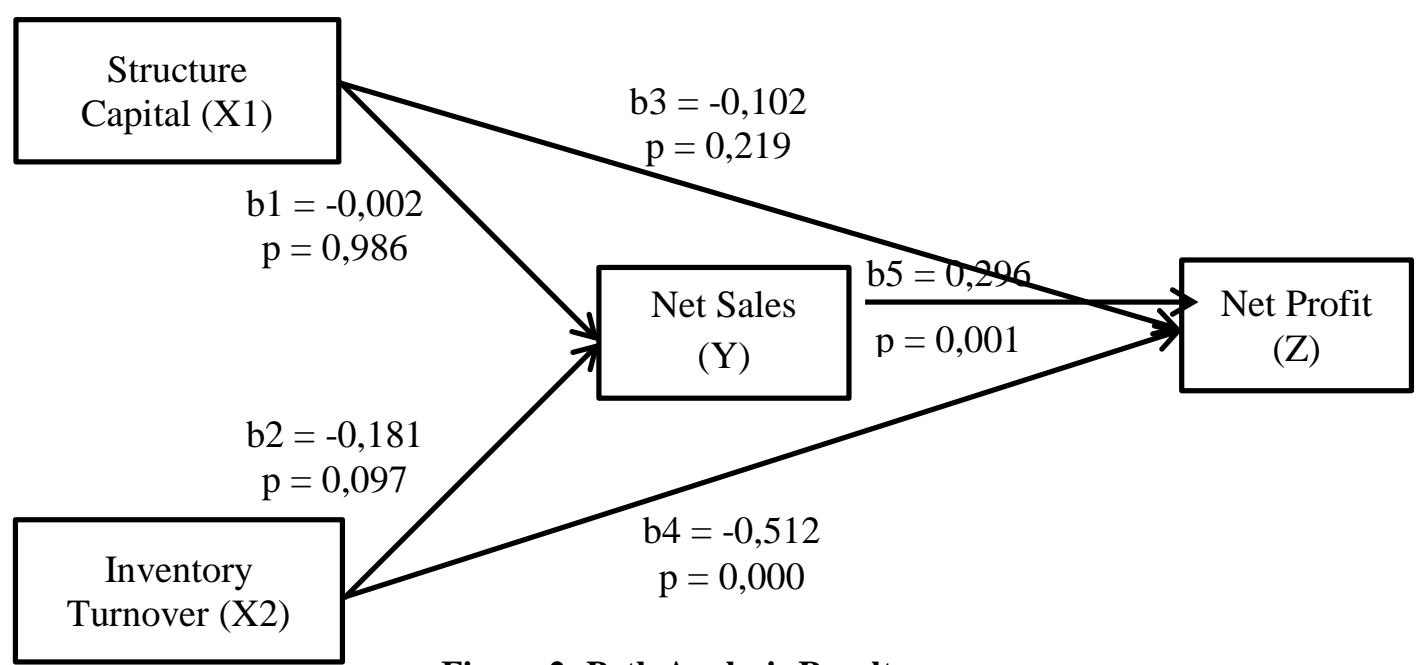

Figure 2: Path Analysis Results

\section{1) The direct and indirect effect of $X 1$ through $Y$ on $Z$}

It is known that the direct effect given by $\mathrm{X} 1$ to $\mathrm{Z}$ is -0.102 . While the indirect effect of $\mathrm{X} 1$ through $\mathrm{Y}$ on $\mathrm{Z}$ is the multiplication between the Beta value of $\mathrm{X} 1$ against $\mathrm{Y}$ and the beta value of $\mathrm{Y}$ against $\mathrm{Z}$, which is $-0.002 \times 0.296=-0.000$. While the total effect given by $\mathrm{X} 1$ to $\mathrm{Z}$ is the direct effect plus the indirect effect, namely $-0.102+-0.000=-0.102$.

Based on the results of the above calculations, it is known that the direct influence value is -0.102 and the indirect effect is 0.000 , which means it is smaller than the direct effect, so it can be concluded that the capital structure variable (X1) has no effect on net income $(\mathrm{Z})$ through Y net sales.

2) The direct and indirect effect of $X 2$ through $Y$ on $Z$

It is known that the direct effect given by $\mathrm{X} 2$ to $\mathrm{Z}$ is -0.512 . While the indirect effect of $\mathrm{X} 2$ through $\mathrm{Y}$ on $\mathrm{Z}$ is the multiplication between the value of Beta X2 and the value of Beta Y to Z, which is $-0.181 \times 0.296=0.115$. While the total effect given by $\mathrm{X} 2$ to $\mathrm{Z}$ is the direct effect plus the indirect effect, which is $-0.512+0.115=-0.397$.

Based on the results of the above calculations, it is known that the direct influence value is -0.512 and the indirect effect is 0.115 which means it is greater than the direct effect so it can be concluded that the inventory turnover variable (X2) indirectly affects net income (Z) through net sales ( Y).

\section{DISCUSSION}

\section{a. Effect of capital structure on net income through net sales}

The results showed that the capital structure had no effect on net sales. This means that the available capital structure is not used either for procuring products or for producing and marketing goods which are expected to encourage sales levels so that it affects company profits, but the capital structure is used for other investments.

Capital structure also has no significant effect on net income $(Z)$. This means that the size of the capital structure does not affect the net profit generated by the company. This is not in accordance with the proposed hypothesis, namely that capital structure has a positive effect on net income. Food and beverage companies show that the average composition of their own capital is greater than foreign capital or debt obtained from investors. So in this condition the debt does not affect the company's profitability.

Path analysis shows that the capital structure (X1) has no effect on net income (Z) through net sales Y. These results explain that the average food and beverage company, especially for the period 2015 - 2019 does not fully use the capital structure to increase productivity so that the capital structure does not affect the increase or decrease in sales. Because the capital structure does not affect the increase or decrease in sales, it does not have an impact on the company's net profit. In other words, even though the company does not focus its capital on increasing production, the inventories owned by food and beverage companies during the research period are still able to meet customer demands.

\section{b. Effect of inventory turnover on net income through net sales}

The results showed that the inventory turnover variable (X1) had no effect on net sales (Y). If the amount of inventory is large, the company must be able to sell goods in large quantities to optimize the inventory turnover rate. This means that sales 
must match the inventory of merchandise. From the results of this study, it can be seen that the average companies in the sample have not been able to manage their inventory properly.

Inventory turnover has a negative effect on net income $(Z)$. This means that the company's inventory turnover rate in this study is quite high but most of the sales transactions are dominated by credit transactions where this is related to the payment of receivables. If the receivables are not repaid on time, it will result in the length of time the receivables turning into cash, while the goods sold have reached the hands of consumers, resulting in low company profitability. This result is not in accordance with research conducted by Purwanti and Rica which states that inventory turnover has a positive and significant effect on net income. [19].

Inventory turnover (X2) indirectly affects net income $(\mathrm{Z})$ through net sales (Y). These results can explain that the higher the inventory turnover rate, the faster the company makes sales. The faster the company sells, the greater the profit potential. So the inventory turnover period needs to be considered to find out how long it takes the company to sell inventory. This is because inventory has a cost. If the inventory turnover is faster, the costs that must be incurred to keep the inventory in good condition will be smaller. Vice versa if the inventory turnover is getting slower, the costs that must be incurred to keep the inventory in good condition will be even greater.

\section{CONCLUSIONS AND RECOMMENDATIONS}

Capital structure has no effect on net income through net sales. This means that the company does not focus on debt to increase production, market and sell products to customers so that there is no significant impact on the net profit generated by the company through sales.

While inventory turnover has an effect on net income through net sales. This means that high inventory turnover will be followed by an increase in company profits. So it can be concluded that the company is able to sell the available products so that it can generate profits regardless of the company selling products with credit or cash transactions.

The hope of the authors for further research is that researchers add independent variables so that research on net income can be explained by a larger percentage. It is expected that food and beverage companies manage or control the capital structure, inventory turnover and sales to be effective so that the expected profit of the company can be achieved.

\section{REFERENCES}

1. Cashmere. 2016. Financial Statement Analysis. Jakarta: King Grafindo Persada

2. Maria, Elisabet \& Iriyadi, Effect of Inventory on Increasing Company Profitability. 2014. Scientific Journal of Unity Accounting. Volume. 2. Number. p. 1-8

3. Wikardi, Lucya \& Wiyani, Natalia. The Effect of Debt to Equity Ratio, Firm Size, Inventory Turnover, Assets Turnover and Sales Growth on Profitability (A Case Study in the Food and Beverage Industry Listed on the IDX for the Period 2011-2015). 2017. Online Journal of Accountants. Volume.2. Number 1. p. $99-118$

4. Naibaho, Erik \& Rahayu, Sri. The Effect of Accounts Receivable Turnover and Inventory Turnover on Profitability (Empirical Study of Food and Beverage Companies Listed on the IDX in 2008-2012). 2014. e-Proceeding of Management: Volume. 1. Number.3 . p. $279-290$

5. Sukadana, I Ketut \& Triaryati, Nyoman. The Effect of Sales Growth, Company Size, and Leverage on Profitability in IDX Food and Beverage Companies. 2018. E-Journal of Unud Management. Volume. 7. Number. 11. p. 6239 - 6268

6. Kristianti, Aprida, Effect of Working Capital and Sales on Net Profit in Automotive Companies Listed on the Indonesia Stock Exchange for the period 2013-2017. 2021. Journal of Elementary Accounting Students. Volume. 1, Number. 1. p. 60 - 76

7. Violita, Resi \& Sulasmiyati, Sri. Effect of Capital Structure on Profitability (Study on Food and Baverages Companies Listed on the IDX in 2013-2016). 2017. Journal of Business Administration (JAB). Volume. 51. Number. 1. p. 138 - 144

8. Novita, Bunga \& Sofia. Effect of Capital Structure and Liquidity on Profitability. 2015. Trisakti Accounting e-Journal. Volume.

2. Number. 1. p. $13-28$

9. Widyamukti, Erlina Yunitasari \& Junianto Wibowo. Effect of Working Capital on Company Sales and Profits (Case Study on Food and Beverage Sector listed on BEI 2011-2014). 2018. JEMAP: Journal of Economics, Management, Accounting and Taxation. Volume. 1. Number. 1. p. $57-68$ 
10. Indriyati, Rizka Suci \& Nanu Hasanuh. The Influence Of Working Capital, Sales and Operating Cost on Net Profit (Empirical Study on Manufacturing Company Sector Consumer Goods Industry Listed in Indonesia Stock Exchange Period 2015 - 2017). 2020. International Journal of Accounting, Taxation, and Business. Volume. 1, Number. 1. p. 86 - 100

11. Mangayak, Elma Natasha. et. al. The Influence of Cash Turnover and Inventory Turnover on Profit Levels in Companies in the Goods and Consumption Industry Sector Listed on the BEI. 2019. EMBA Journal. Volume. 7 Number. 3. p. 3608 - 3617

12. Hidayat, Andi Wahyu \& Nandan A. Hidayat. Influence of Inventory on Profit Through Sales on CV. Rizky Bike Indramayu. 2018. Investment Journal. Volume. 4. Number. 1. p. 52-62

13. Subramayam, K. 2017. Analysis of Financial Reports Edition 11. Jakarta: Salemba Empat

14. Cashmere. (2015), Financial Statement Analysis. Jakarta: Rajawali Pers Maharani and Andi, 2020)

15. Putri, Maharani Dewi and Andi Wijayanti. The Effect of Cash Turnover and Inventory Turnover on Company Profitability (Study on Food and Beverage Companies Listed on the Indonesia Stock Exchange Period 2013-2018). 2020. Journal of Business Administration. Volume. IX, No. IV. p. 402-411

16. Mulyadi. (2016). Accounting information system. Jakarta: Salemba Empat

17. Subramanyam, K. R. and John J. Wild. 2015. Analysis of Financial Reports. Translator Dewi Y. Jakarta: Salemba Empat

18. Harry. 2015. Analysis of Financial Statements. Issue 1. Yogyakarta. Center For Academic Publishing Services

19. Purwanti \& Rica Putri Aryani. The Effect of Accounts Receivable Turnover and Inventory Turnover on Net Profits in Food and Beverage Manufacturing Companies Listed on the Indonesia Stock Exchange. 2019. Journal of Research, Development of Management and Accounting Sciences, STIE Putra Perdana Indonesia. Volume. 19. p. 1961 - 1971 